магазина самостоятельно. Это обусловлено большим уровнем занятости населения, отсутствием времени на посещение определенных магазинов. Благодаря созданию интернетплатформы по реализации органической продукции на основе козьего молока, у производителей появляется преимущество перед крупнейшими агрохолдингами.

Вектор развития органической молочной продукции в большинстве будут выбирать фермеры и малые производства. В объемах крупных молочных хозяйств трудоемко наладить органическое производство. Производство козьего молока остается наиболее выгодным при выборе данной стратегии продвижения по многим пунктам: периоду перехода, наименьшей площадью фермы, меньшими затратами на корм и воду, наименьшей площадью пастбища.

Результаты проведенных исследований подтвердили целесообразность расширения рынка козьего молока. А создание интернет-ресурса по реализации органической продукции на основе козьего молока, позволит большую часть населения привлечь к потреблению данного продукта.

\section{Список литературы:}

1. Федеральный закон "Об органической продукции и о внесении изменений в отдельные законодательные акты Российской Федерации" от 03.08.2018 N 280-Ф3

2. Перова Юлия Владимировна Развитие рынка молочной продукции // Вестник СамГУ. 2007 . №5-1. URL: https://cyberleninka.ru/article/n/razvitierynka-molochnoy-produktsii .

3. Гетманец Валентина Николаевна Особенности переработки козьего молока // Вестник АГАУ. 2016. №5 (139). URL: https://cyberleninka.ru/article/n/osobennostipererabotki-koziego-moloka.

4. ГОСТ 31449-2013 Молоко коровье сырое. Технические условия

5. ГОСТ 32940-2014 Молоко козье сырое. Технические условия

6. ГОСТ 33980-2016 «Продукция органического производства. Правила производства, переработки маркировки и реализации»

7. ГОСТ Р 56104-2014 «Продукты пищевые органические. Термины и определения»

8. ГОСТ Р 57022-2016 «Продукция органического производства. Порядок проведения добровольной сертификации органического производства»

9. Нормы технологического проектирования козоводческих объектовНТП-АПК 1.10.03.002-02

10. Приказ Министерства сельского хозяйства от 13 декабря 2016 г. № 551 "Об утверждении Ветеринарных правил содержания крупного рогатого скота в целях его воспроизводства, выращивания и реализации"

11. Специализированный сайт/Новости и аналитика молочного рынка https://milknews.ru/longridy/rossiya-

kozovodstvo-moloko.html

12. Маркетинговые исследования рынка молочной продукции Косикова Ю.А.В сборнике: Передовые пищевые технологии: состояние, тренды, точки роста. Сборник научных трудов I научнопрактической конференции с международным участием. 2018. С. 194198.

13. Состояние и перспективы развития отрасли молочной продукции в России Григорян М.Ю., Косикова Ю.А.В книге: Общеуниверситетская студенческая конференция студентов и молодых ученых "День науки". Сборник материалов конференции: в 6 частях. 2017. С. 160-162.

14. Современное состояние и прогноз развития производства детского питанияПеченая Л.Т., Коршик Т.С., Цветлюк Л.С., Болдычева A.Г.Health, Food\&Biotechnology. 2019. T. 1. № 1. C. 92102.

15. Использование кластерного подхода для повышения эффективности регионального молочного подкомплекса Сафронова Ю.В., Толкачева С.В., Столярова О.А.Экономика: вчера, сегодня, завтра. 2016. № 3. C. 80-89.

УДК 332.132

ЭКОНОМИКА РЕСПУБЛИКИ ТАТАРСТАН В 1990-Е ГОДЫ

DOI: $10.31618 /$ ESU.2413-9335.2021.1.86.1360

Судьин Андрей Владимирович

кандидат эконом. наук, старший научный сотрудник,

Институт востоковедения РАН, г. Москва.

\title{
ECONOMY OF THE REPUBLIC OF TATARSTAN IN THE 1990S
}

Andrey V. Sudyin

PhD (Economics), senior researcher, Institute of Oriental Studies of the RAS, Moscow 


\section{АННОТАЦИЯ}

В статье анализируется экономическая ситуация в Татарстане в период с 1990 по 1999 гг. Показана динамика объема производства в основных отраслях экономики, таких как нефтедобыча, нефтехимия, энергетика, машиностроение, сельское хозяйство. Рассматривается экономическая политика правительства республики.

\section{ABSTRACT}

The article analyzes the economic situation in Tatarstan in the period from 1990 to 1999. The dynamics of production in the main sectors of the economy, such as oil production, petrochemicals, energy, mechanical engineering, and agriculture, are shown. The economic policy of the Government of the republic is considered.

Ключевые слова: Татарстан, экономика, основные отрасли, экономическая политика.

Keywords: Tatarstan, economy, main industries, economic policy.

В 1990-е годы Татарстан, как и прочие регионы, входящие в Российскую Федерацию, пережил весьма непростой этап перехода от прежней советской экономической модели к новой рыночной экономике. Предложенная президентом Минтимером Шаймиевым и правительством республики политика мягкого вхождения в рынок была основана на концепции социального государства и формулировалась следующим образом: «Модель Татарстана — это модель социально ориентированной экономики, с устойчивым типом роста, интегрированной в мировое хозяйство, приводимой в действие внешними инвестициями за счет высокой добавленной стоимости товаров и услуг при активной регулирующей роли государства» [1] Данная экономическая политика первоначально давала неплохие результаты. Так, в 1992-1993 гг. темпы падения промышленного производства в Татарстане были одни из самых низких среди российских регионов.

Правда, в 1994 году они были больше, чем в целом по России. Несмотря на то, что руководство республики стремилось оттянуть и смягчить проведение непопулярных экономических реформ, намеченных федеральным правительством, многие из них в Татарстане все же были проведены, поскольку этого требовали объективные законы рыночной экономики. Некоторые из реформ были проведены радикальным образом, некоторые более осторожно, с учетом конкретной экономической ситуации.

К 1995 году спад в экономике республики замедлился, и в ряде отраслей даже начался рост. В 1995 году промышленное производство увеличилось на 2\%, а в 1996 году — на 3,5\%, в то время как в целом по России оно продолжало сокращаться. Однако этот рост произошел в основном за счет отраслей, связанных с добычей и переработкой нефти. В других отраслях промышленности наблюдался глубокий кризис, в том числе в такой важной для Татарстана отрасли, как машиностроение, где в целом за 5 лет (с 1991 по 1996 гг.) производство сократилось в два с лишним раза. Спад производства в «ненефтяных» отраслях, рост неплатежей и прочие кризисные явления поставили под сомнение эффективность политики «мягкого вхождения в рынок». Но республиканские власти не стали отказываться от нее, по крайней мере формально. Тем более что доходы от нефти и нефтепродуктов позволяли сглаживать последствия негативных экономических тенденций.
Зависимость экономики республики от нефти в постсоветское время усилилась, несмотря на истощение местных нефтяных ресурсов. Добыча нефти в Татарстане осуществляется с 1943 года. Тогда годовой объем добычи составил всего 4,2 тысячи тонн. Но уже в 1955 году он достиг 13 млн тонн. А в 1970 году впервые был перейден 100миллионный рубеж. В 1975 году добыча составила исторический максимум - 103,7 млн тонн, после чего она пошла на спад вследствие исчерпания легкодоступных запасов нефти [2].

В 1990 году добыча сократилась до 34,5 млн тонн, в 1991 - до 32,7 млн, в 1992 - до 30,0 млн, в 1993 - до 26,0 млн и в 1994 - до 24,0 млн тонн. Таким образом, с 1990 по 1994 гг. годовой объем добытой нефти в Татарстане уменьшился на $30,4 \%$. В 1995 году он немного вырос - до 25,5 млн тонн. В 1996 году добыча составила 25,4 млн тонн, в 1997 — 25,5 млн, в 1998 - 25,8 млн в 1999 году — 26,3 млн тонн [3].

Небольшой рост добычи во второй половине 1990-х годов был обеспечен за счет малых нефтяных компаний, в то время как годовой объем нефти, добываемой крупнейшей компанией «Татнефть», с 1993 по 1999 гг. практически не изменился и остался на уровне 23 млн тонн в год (после резкого падения в начале 1990-х годов) [3]. Малые нефтяные компании в республике появились в 1997 году, после указа Президента РТ Минтимера Шаймиева «О мерах по увеличению нефтедобычи в РТ». Данный указ был издан в феврале 1997 года, и в том же году появились первые 14 малых нефтедобывающих компаний. Необходимость их создания была обусловлена тем, что крупным корпорациям, как правило, невыгодно заниматься небольшими или исчерпанными месторождениями, где добыча нефти требует тщательного, скрупулезного подхода. Для этой роли больше подходят малые компании, в том числе специально созданные для работы на том или ином конкретном месторождении.

Большое внимание в Татарстане в 1990-е годы уделялось поиску новых запасов нефти и, параллельно этому, повышению эффективности использования имеющихся нефтяных ресурсов. В частности, было решено, наряду с нефтедобывающей промышленностью, развивать нефтепереработку и нефтехимию. В республике уже был создан ряд нефтехимических предприятий, в том числе комбинат «Нижнекамскнефтехим», введенный в строй в 1967 году. В 1990-е годы он был одним из крупнейших в России комбинатов подобного 
профиля и, в частности, ведущим производителем синтетического каучука. Однако переработка нефти, включая производство бензина, до недавнего времени осуществлялась в основном за пределами Татарстана. Поэтому в республике было принято решение о создании замкнутого цикла добычи и переработки нефти - «от скважины до бензоколонки». В частности, было намечено построить крупный нефтеперерабатывающий завод в Нижнекамске. Акционерами нового комбината стали четыре татарстанские компании, в том числе «Нижнекамскнефтехим» и основная нефтедобывающая компания Татарстана «Татнефть». Вокруг «Татнефти» вообще было решено создать своего рода холдинг, включающий все стадии добычи и переработки нефти, а также нефтехимию. Несмотря на сокращение объема добычи с 1990 по 1999 гг. почти на 1/3, компания «Татнефть» в начале 2000-х годов занимала четвертое место в России по добыче нефти. А после создания холдинга ее роль в нефтяном секторе российской экономики стала еще более значительной.

К концу 1990-х спад в большинстве «ненефтяных» отраслей экономики прекратился, а в некоторых из них даже наметилась тенденция к росту производства. В 1999 году общий объем промышленной продукции возрос на 2,1\%, достигнув 100,5 млрд рублей. При этом следует отметить, что Татарстану в 1990-е годы удалось сохранить (несмотря на сокращение объема заказов и, следовательно, падение производства) костяк оборонных и «полуоборонных» предприятий, производящих самолеты, вертолеты, скоростные катера, оптико-механические приборы и т.д.

Несмотря на все трудности, продолжил функционировать и бывший флагман машиностроения - КамАЗ. Этот завод-гигант, рассчитанный на ежегодное производство 150 тыс. грузовиков и реально производивший по 120 тыс. машин в год, в 1990 году стал первым в СССР акционерным обществом. Согласно постановлению Совета Министров СССР, $51 \%$ акций завода должны были остаться в общесоюзной собственности, а остальные было намечено продать. В результате процесса приватизации акционерами КамАЗа стали 230 предприятий и организаций [4]. Прежде основная часть продукции КамАЗа реализовывалась в рамках государственного заказа. В связи с его резким сокращением в 1990-е годы АО столкнулось с серьезными финансовыми проблемами. Положение еще более усугубилось после пожара, уничтожившего завод по производству двигателей, a также вследствие непродуманной политики заимствования внешних финансовых ресурсов. В результате объем производства на КамАЗе в 1997 году сократился до 12,7 тыс. грузовиков, а в 1998 году - до 3,3 тыс. Суммарный долг завода превысил миллиард долларов. Чтобы спасти КамАЗ (фактически ставший банкротом) от полного краха правительство Татарстана вынуждено было взять ситуацию на нем под свой контроль и принять активное участие в реструктуризации огромной задолженности. В результате энергичных мер республиканского руководства и при поддержке федерального правительства КамАЗу удалось отсрочить выплату долгов и «оживить» производство грузовиков. Параллельно начался широкомасштабный выпуск легковых малолитражек «Ока». Со временем предполагалось наладить производство малолитражек и на другом автозаводе - в Елабуге, основанном в 1985 году.

Что касается такой важнейшей отрасли экономики, как энергетика, то она в постсоветский период также переживала серьезные трудности. В середине 1980-годов в республике была реализована довольно дорогостоящая программа перевода ТЭЦ с угля на газ и, в меньшей степени, на мазут. Эта мера в то время представлялась вполне оправданной, поскольку газ является оптимальным топливом для теплоэлектростанций - как с техникоэкономической, так и с экологической точек зрения. Однако изменение общей экономической ситуации в России в 1990-е годы привело к тому, что газ стало более выгодным экспортировать, а не использовать как топливо внутри страны (учитывая хронические неплатежи со стороны его местных потребителей). У «Газпрома», монопольно контролирующего добычу газа в России, возникли серьезные разногласия с региональными энергетическими компаниями относительно поставок газа и платежей за него. Компания «Татэнерго», являвшаяся крупным должником «Газпрома», в свою очередь, сама постоянно сталкивалась с неплатежами за тепло и электроэнергию. Положение усугублялось тем, что основными должниками «Татэнерго» были нефтехимические предприятия, которые, в соответствии с решением правительства Татарстана, получали электроэнергию по льготным ценам (учитывая важность нефтехимии для экономики республики).

Поэтому к концу 1990-х годов в Татарстане были определены два основных пути решения энергетической проблемы. Во-первых, это экономия энергии. В связи с этим был принят специальный закон «Об энергосбережении». Второй путь - это увеличения мощности ГЭС в Набережных Челнах, для чего было решено поднять уровень Нижнекамского водохранилища еще на 6 метров (с 62 до 68 м). С одной стороны, это позволило бы увеличить выработку электроэнергии на 1,4 млрд киловатт-часов (для чего потребовалось бы сжигать 420 млн кубометров газа в год). Но, с другой стороны, по мнению местных экологов, это привело бы к затоплению еще 86 тыс. гектаров земельных угодий. Правда, правительственные эксперты заверили, что данные земли уже были выведены из хозяйственного оборота и должны были быть затоплены еще в прежние годы, если бы не приостановка заполнения водохранилища в период перестройки под давлением общественного мнения. К тому же общая площадь затопленных водохранилищем земель должна была составить лишь 2,3\% земельного фонда республики. В 2001 году Татарстан и Башкортостан совместно решили поднять уровень водохранилища до 63,5 м. В 2002 
году к этому решению присоединилась Удмуртия. Однако подъем уровня воды до отметки 68 м (как это было определено первоначальным проектом) было решено на время отложить - до определения возможного экологического риска и убытков от вывода из сельскохозяйственного оборота затапливаемых земель.

В постсоветском Татарстане вообще велась активная дискуссия об эффективности использования земельных, в том числе сельскохозяйственных ресурсов. В 1998 году был принят республиканский Земельный кодекс, разрешавший куплю и продажу земли. Причем покупать ее смогли не только татарстанцы и россияне в целом, но и граждане зарубежных государств, а также лица без гражданства. Правда, при этом был установлен ряд ограничений. Например, иностранцы смогли покупать землю только из государственного резерва. Что касается земель сельскохозяйственного назначения, то их смогли приобретать только те, кто обладал соответствующей квалификацией. В республике всячески стимулировалось развитие фермерства. Число фермерских хозяйств к началу 2000 года составило около 2 тыс., т.е. возросло втрое, по сравнению с началом 1993 года. Но основная часть сельскохозяйственных земель по-прежнему осталась в пользовании коллективных хозяйств, многие из которых стали хроническими должниками. Выходя из колхозов, крестьяне вместе с земельным паем унаследовали и часть долгов, что явилось серьезным тормозом на пути развития фермерства.

Несмотря на все трудности, связанные с перестройкой сельского хозяйства, в некоторых его подотраслях в 1990-е годы был отмечен реальный рост. Так, валовой сбор зерна в республике в 1996 году на 30\% превысил уровень 1991 года. В результате Татарстан по производству зерновых культур вышел в лидеры среди российских регионов [5]. И в дальнейшем он оставался в числе крупнейших производителей зерна, несмотря на сильнейшую засуху 1998 года и другие неблагоприятные погодные факторы.

Какое-то время в Татарстане сохранялся чуть ли не самый низкий в России уровень цен на основные потребительские товары. Но уже с 1994 года цены стали быстро расти. Правда, и к 2000 году потребительская корзина в республике была дешевле, чем в целом по Российской Федерации. Но эта разница уже была не столь заметна, как 1990-е годы. Одновременно с этим сократился и разрыв в размерах средней заработной платы, которая в республике также была ниже, чем в целом по России. Однако минимальный размер зарплаты в Татарстане в 1990-е годы был выше, чем в среднем по стране. С 1997 по 2000 год он составлял 350 тыс., т.е. был в четыре с лишним раза выше общероссийского уровня, равного 83,5 тыс. рублей.

Установление такой высокой минимальной зарплаты было одним из проявлений широко разрекламированной в республике социальной рыночной политики (с акцентом на слове «социальная»). Эта политика предусматривала целый комплекс мер по социальной защите населения. Хотя далеко не все намеченные программы удалось выполнить, все же реально было сделано не так уж мало. Благодаря доходам от нефти и крупным налоговым льготам правительство Татарстана имело возможность выделять довольно большие средства на социальные проекты. Например, во второй половине 1990-х годов республика занимала одно из первых мест в России по объему жилищного строительства, в том числе по строительству муниципального жилья для очередников. В Казани началась реализация широкомасштабной программы переселения жителей деревянных трущоб в новые дома. И в целом республика показывала неплохие (по сравнению с большинством других российских регионов) показатели в социальной сфере.

Таким образом, несмотря на все сложности переходного периода, Татарстан в конце 1990-х годов оставался одним из наиболее благополучных в экономическом смысле субъектов Российской Федерации. И это обстоятельство во многом способствовало успешному экономическому развитию республики в последующие годы.

\section{Список использованной литературы}

1. Государственная программа экономического и социального прогресса Республики Татарстан. - Казань, 1996, С. 27.

2. История добычи нефти на территории Татарстана / Информационно-деловой проект «Oil.Tatar», 14 октября 2015. URL: http://neft.tatar/статьи/нефтянаяпромышленность/история-добычи-нефти-натерритории-татар.html.

3. Борисов Д., Мустафин А. Перспективы дальнейшего развития нефтегазового сектора Республики Татарстан: возможности и риски // Нефтегазовая вертикаль (электронная версия). M., 12.08.2013. URL: http://www.ngv.ru/pr/perspektivy-dalneyshegorazvitiya-neftegazovogo-sektora-respubliki-tatarstanvozmozhnosti-i-riski-/?sphrase_id=687483.

4. Автомобильная промышленность // Коммерсанть Власть. - М., 2001, № 39, С. 52.

5. Моя Казань / Сайт столицы Татарстана. URL: http://kazan.ws/cgibin/republic/print.pl?action=view_cul\&id_cul=714\&i d_razdel=11\&id_sub=122\&id_sub_sub\&wh=sub. 